\title{
KEY SUCCESS FACTOR GOOD GOVERNMENT GOVERNANCE SERTA PENGARUHNYA TERHADAP KINERJA PEMERINTAH \\ (Survey pada Pemerintah Kabupaten Gunungkidul)
}

Oleh:

Handi Yuniar Lestiawan (Universitas Muhammadiyah Yogyakarta)

Bambang Jatmiko (Universitas Muhammadiyah Yogyakarta)

\begin{abstract}
In this era, local government performance in Indonesia is weak because there are many abuse of authority everywhere, like corruption, collusion, and nepotism. Each of local government should apply the principles of good government governance in the government environtment, this is to improve performnace of local government. In this research good government governance principle contain transparancy, accountability, residents particpation, fairness, and responsibility. The purpose of this research is analyze dan explain the empirical evidence about the influence of transparancy, accountability, residents participation, fairness, and responsibility to the performance of local government. This research use primary data. Primary data derived from quistionnaire which share to employee of local government in Gunungkidul. This research involve 100 sample's. The sample is determined by Slovin sampling method. Sample in this research derived from the employee of local government and Gunungkidul's residents. Analitycal method use multiple regression. The result of this research is transparancy, accountability, and residents participation don't have influence to the performance of local government, but fairness and responsibility have a positive and significant influence to the performance of local government.
\end{abstract}

Keyword: Good Government Governance, performance of local government. 


\section{PENDAhuluaN}

1. Latar Belakang

Sebuah organisasi, baik swasta maupun publik terbentuk atas adanya asas teori keagenan. Teori keagenan menjelaskan tentang masalah yang pasti terjadi pada organisasi, dimana terjadi perbedaan kepentingan antara agent dan principal yang dapat menimbulkan adanya asimetri informasi. Berdasarkan sudut pandang teori keagenan diatas, hubungan antara masyarakat dengan pemerintah merupakan salah satu contoh dari hubungan antara prinsipal dan agen. Pemerintah pasti menginginkan pemerintahannya dapat dikelola dengan baik, yaitu dari segi keuangannya maupun dari segi manajemennya. Masyarakat pun berpikir demikian, mereka berkeinginan pemerintahan di daerahnya dapat dikelola dengan baik dan jauh dari praktek korupsi, kolusi, dan nepotisme. Untuk mewujudkan pemerintahan yang baik kedua kepentingan atau keinginanan tersebut, yaitu dari masyarakat dan pemerintah harus sejalan. Dalam beberapa tahun terakhir ini, praktek KKN sedang marak-maraknya terjadi pada lingkungan pemerintah, baik pusat maupun daerah. Seperti yang diungkapkan oleh Wati dkk. (2010) dalam beberapa tahun terakhir, permasalahan hukum terutama berkaitan dengan korupsi, kolusi, dan nepotisme (KKN) dengan segala praktiknya seperti penyalahgunaan wewenang, penyuapan, pemberian uang pelicin, pungutan liar, pemberian imbalan atas dasar kolusi dan nepotisme serta penggunaan uang negara untuk kepentingan pribadi telah menjadi perhatian masyarakat dan dianggap sebagai suatu hal yang lazim terjadi di negara ini.

Untuk mengatasi kasus KKN yang sedang marak di Indonesia ini, pemerintah diwajibkan untuk menerapkan good governance pada pemerintahannya. Berbagai upaya sudah semestinya dilakukan oleh pemerintah untuk mencapai good government governance, seperti yang diungkapkan oleh Sari (2013) salah satu bentuk penerapan prinsip tata kelola pemerintahan yang baik dalam bidang pengelolaan keuangan negara/daerah adalah melalui pemberlakuan kewajiban kepada seluruh pemerintah daerah untuk menyusun Laporan Keuangan Pemerintah Daerah (LKPD) sebagai salah satu bentuk pertanggungjawaban pengelolaan keuangan daerah yang transparan dan akuntabel kepada seluruh pengguna laporan keuangan pemerintah daerah, yakni masyarakat, para wakil rakyat, lembaga pengawas, lembaga pemeriksa, pihak yang memberi atau berperan dalam proses donasi, investasi, dan pinjaman, serta pemerintah daerah itu sendiri.

Dasar dari perwujudan penciptaan tata kelola pemerintahan yang baik adalah Undang-Undang Administrasi Publik (AP) yang tertuang pada TAP MPR RI No. XI/MPR/1999 tentang Penyelenggara Negara yang bersih dan bebas KKN dan UU No. 28 Tahun 1999 tentang Penyelenggara Negara yang bersih dan Bebas Korupsi, Kolusi, dan Nepotisme. Selain UU AP, dasar penciptaan good government governance bercermin pada PP No. 71 Tahun 2010 tentang standar akuntansi pemerintahan (SAP).

Good government governance mengandung beberapa prinsip. Dalam penerapannya good government governance dikenal dengan adanya lima prinsip utama, kelima prinsip tersebut adalah transparansi, akuntabilitas, responbilitas, independensi, dan keadilan (Pratolo, 2010). Apabila prinsip itu diterapkan dalam suatu pemerintahan daerah, maka good government governance akan tercapai dan kinerja sebuah pemda akan menjadi lebih baik. Seperti yang diungkapkan Hardiwinoto (2004) 
bahwa prinsip-prinsip good governance akan menjamin terciptanya pertumbuhan ekonomis. Prinsip-prinsip tersebut dapat mencerminkan kinerja pemda untuk suatu periode tertentu. Kinerja pemerintah daerah merupakan hal yang penting untuk diketahui oleh masyarakat. Kinerja pemerintah daerah dapat diukur oleh beberapa indikator, diantaranya yaitu Value For Money (VFM) dan Laporan Akuntabilitas Kinerja Instansi Pemerintah (LAKIP). Selain melalui LAKIP, baik atau

Tabel 1.

Perkembangan Opini BPK Pemerintahan Provinsi D. I. Yogyakarta dari Tahun 2009-2013 buruknya kinerja sebuah pemerintah daerah dapat dilihat dari opini yang dikeluarkan oleh Badan Pemeriksa Keuangan (BPK) setiap tahunnya.

Hasil Pemeriksaan BPK RI semester I tahun 2014 menunjukkan bahwa diantara semua kabupaten dan kota di Provinsi D. I. Yogyakarta hanya kabupaten Gunungkidul yang selalu mendapatkan opini WDP dari BPK. Ini menunjukkan bahwa kinerja pemerintah Kabupaten Gunungkidul masih terbilang belum memuaskan.

\begin{tabular}{|l|c|c|c|c|c|}
\hline \multirow{2}{*}{\multicolumn{1}{|c|}{ LKPD }} & \multicolumn{5}{c|}{ OPINI BPK RI } \\
\cline { 2 - 6 } & Tahun 2009 & Tahun 2010 & Tahun 2011 & Tahun 2012 & Tahun 2013 \\
\hline Prov. D. I. Yogyakarta & WDP & WTP-DPP & WTP-DPP & WTP & WTP \\
\hline Kab. Bantul & WDP & WDP & WDP & WTP-DPP & WTP \\
\hline Kab. Gunung Kidul & WDP & WDP & WDP & WDP & WDP \\
\hline Kab. Kulon Progo & WDP & WDP & WDP & WDP & WTP-DPP \\
\hline Kab. Sleman & WDP & WDP & WTP-DPP & WTP-DPP & WTP \\
\hline Kota Yogyakarta & WTP-DPP & WTP-DPP & WTP-DPP & WTP-DPP & WTP \\
\hline
\end{tabular}

Sumber: IHPS BPK RI semester I Tahun 2014

Keterangan:

WTP : Opini Wajar Tanpa Pengecualian (unqualified opinion)

WTP-DPP : Opini Wajar Tanpa Pengecualian Dengan Paragraf

Penjelas (unqualified opinion with modified wording)

WDP : Opini Wajar Dengan Pengecualian (qualified opinion)

Berdasarkan penjabaran diatas maka penelitian ini berjudul "Key Success Faktor Good Government Governance serta pengaruhnya terhadap Kinerja Pemerintah Daerah"

Penelitian ini mengkaji ulang dari penelitian yang dilakukan oleh Mulyawan (2009), Yusuf (2009), dan Pratolo (2010). Perbedaan penelitian ini dengan penelitian sebelumnya adalah pergantian objek penelitian, yaitu peneliti mengganti objek penelitian menjadi pemerintah Kabupaten Gunungkidul yang melibatkan Badan dan Dinas didalamnya. Perbedaan kedua adalah pada penelitian ini peneliti ingin menguji pengaruh prinsip good government governance secara parsial, karena pada penelitian terdahulu hanya mengungkapkan pengaruh prinsip good government governance secara simultan (bersama).

2. Batasan Masalah

Seperti yang kita ketahui terdapat berbagai jenis prinsip good government governance yang diungkapkan oleh beberapa peneliti terdahulu, namun prinsip good government governance yang digunakan dalam penelitian ini hanya ada lima, yaitu transparansi, akuntabilitas, partisipasi masyarakat, keadilan, dan responsibilitas.

3. Rumusan Masalah 
Berdasarkan uraian dari latar belang di atas maka peneliti dapat merumuskan masalah sebagai berikut:
a. Apakah prinsip transparansi berpengaruh terhadap kinerja pemerintah daerah?
b. Apakah prinsip akuntabilitas berpengaruh terhadap kinerja pemerintah daerah?
c. Apakah prinsip partisipasi masyarakat terhadap kinerja pemerintah daerah?
d. Apakah prinsip keadilan berpengaruh terhadap kinerja pemerintah daerah?
e. Apakah prinsip pertanggungjawaban berpengaruh terhadap terhadap kinerja pemerintah daerah?

\section{Tujuan Penelitian}

Berdasarkan uraian rumusan masalah diatas maka penelitian ini bertujuan:

a. Untuk mendapatkan bukti empiris pengaruh prinsip transparansi terhadap kinerja pemerintah daerah.

b. Untuk mendapatkan bukti empiris pengaruh prinsip akuntabilitas terhadap kinerja pemerintah daerah.

c. Untuk mendapatkan bukti empiris pengaruh prinsip partisipasi masyarakat terhadap kinerja pemerintah daerah.

d. Untuk mendapatkan bukti empiris pengaruh prinsip keadilan terhadap kinerja pemerintah daerah.

e. Untuk mendapatkan bukti empiris pengaruh prinsip responsibilitas terhadap kinerja pemerintah daerah.

\section{Manfaat Penelitian}

Terdapat beberapa manfaat yang penulis coba untuk sampaikan dalam penelitian ini:

a. Manfaat Teoritis

Menjadi literatur tambahan bahan skripsi di perpustakaan Universitas Muhammadiyah Yogyakarta.

b. Manfaat Praktik
1). Bagi pemerintah daerah
khususnya pemerintah Kabupaten Gunungkidul, dapat

dijadikan evaluasi kinerja untuk periode selanjutnya.

2). Bagi perguruan tinggi di Indonesia, dapat dijadikan jurnal pendukung penelitian.

3). Bagi peneliti selanjutnya, semoga dapat menjadi referensi pustaka penelitian.

\section{TINJAUAN PUSTAKA}

6. Landasan Teori

a. Teori Keagenan

Teori keagenan menjelaskan tentang masalah yang pasti terjadi pada organisasi, dimana terjadi perbedaan kepentingan antara agent dan principal yang dapat menimbulkan adanya asimetri informasi. Beberapa peneliti terdahulu mendefinisikan teori keagenan secara berbeda. Jensen dan Meckling dalam Santoso dan Pambulum (2008) mendefinisikan bahwa hubungan keagenan sebagai sebuah kontrak dimana satu atau lebih (principal) menyewa orang lain (agent) untuk melakukan beberapa jasa untuk kepentingan mereka dengan mendelegasikan beberapa wewenang pembuatan keputusan kepada agen. Sedangkan menurut Rustiarini (2010) hubungan keagenan adalah sebuah kontrak antara pihak pemegang saham dan pihak manajer perusahaan. Teori keagenan dilandasi oleh beberapa asumsi (Jensen dan Meckling dalam Hapsari, 2011). Asumsi-asumsi tersebut dibedakan menjadi tiga jenis, yaitu asumsi tentang sifat manusia, asumsi keorganisasian dan asumsi informasi.

b. Good Government Governance

Good governance merupakan proses yang menekankan pada bagaimana suatu organisasi dapat meningkatkan kinerjanya dan terciptanya masyarakat yang madani. Beberapa peneliti mengungkapkan definisi good governance secara berbeda-beda. LAN dalam Garnita (2008) mengungkapkan bahwa good governance adalah proses penyelenggaraan kekuasaan negara 
dalam melaksanakan penyediaan publc goods and service. Good governance merupakan tata kelola yang baik pada suatu usaha yang dilandasi oleh etika profesional dalam berusaha/berkarya. (Trisnaningsih, 2007). Widyananda dalam Wati dkk. (2010) berpendapat bahwa good governance juga dimaksudkan sebagai suatu kemampuan manajerial untuk mengelola sumber daya dan urusan suatu negara dengan cara-cara terbuka, transparan, akuntabel, equitable, dan responsif terhadap kebutuhan masyarakat.

$$
\text { Good government }
$$

governance mengandung beberapa prinsip. Beberapa peneliti mengungkapkan prinsip good government governance secara berbeda-beda. Badjuri dan Trihapsari dalam Wati dkk. (2010) mengungkapkan bahwa dalam pemerintahan yang baik atau good governance ditandai dengan tiga pilar utama yang merupakan elemen dasar yang saling berkaitan. Ketiga elemen dasar tersebut adalah partisipasi, transparansi dan akuntabilitas. Sari (2013), mengungkapkan bahwa prinsip pengelolaan yang baik seperti transparansi, keterbukaan, akuntabilitas, partisipasi, keadilan, dan kemandirian harus ada dalam tata kelola pemerintah yang baik. Rahadian (2008) mengatakan bahwa nilai seperti efisiensi, keadilan, transparansi, partisipasi, dan akuntanbilitas dapat diukur secara mudah dalam praktik penyelenggaraan pelayanan publik.

\section{c. Transparansi}

Transparansi bisa diartikan sebagai keterbukaan informasi, baik dalam proses pengambilan keputusan maupun dalam mengungkapkan informasi material dan relevan mengenai perusahaan. Prinsip transparansi ini menghendaki adanya keterbukaan dalam melaksanakan proses pengambilan keputusan dan keterbukaan dalam penyajian (disclosure) informasi yang dimiliki perusahaan (Hapsari, 2011). Rawlins dalam Ridha dan Basuki (2012) menjelaskan definisi transparansi secara operasional sebagai berikut, transparansi adalah upaya yang secara sengaja menyediakan semua informasi yang mampu dirilis secara legal baik positif maupun negatif secara akurat, tepat waktu, seimbang, dan tegas, dengan tujuan untuk meningkatkan kemampuan penalaran publik dan mempertahankan tanggung jawab organisasi atas tindakan, kebijakan, dan praktiknya.

Berdasarkan definisi diatas, maka secara umum, transparansi dapat diartikan sebagai konsep atau prinsip yang mengedepankan kejujuran pada sebuah organisasi dalam menyajikan informasinya berkaitan kinerja keuangan maupun kinerja manajerialnya.

d. Akuntabilitas

Akuntabilitas dapat diartikan sebagai bentuk pertanggungjawaban pimpinan pemerintah daerah atas keputusan apa yang diambil. Pengambilan keputusan tidak boleh merugikan salah satu pihak, baik pihak internal maupun eksternal seperti masyarakat. Mardiasmo dalam Garnita (2008) berpendapat bahwa akuntabilitas publik adalah kewajiban pihak pemegang amanah (agent) untuk memberikan pertanggungjawaban, menyajikan, melaporkan, dan mengungkapkan segala aktivitas dan kegiatan yang menjadi tanggungjawabnya kepada pihak pemberi amanah (principal) yang memiliki hak dan kewenangan untuk meminta pertanggungjawaban tersebut.

Garnita (2008) menyatakan bahwa aspek yang terkandung dalam pengertian akuntabilitas adalah bahwa publik mempunyai hak untuk mengetahui kebijakan-kebijakan yang diambil oleh pihak-pihak yang mereka beri kepercayaan. Menurut Rosjidi dalam Garnita (2008) Akuntabilitas dibedakan menjadi dua tipe, yaitu akuntabilitas internal dan akuntabilitas eksternal. 
e. Partisipasi Masyarakat

Dalam organisasi publik, partisipasi masyarakat menjelaskan tentang bagaimana masyarakat ikut andil dalam segala hal yang berhubungan untuk pengambilan keputusan yang demokratis, terutama saat ikut serta dalam pemecahan masalah pemda. Menurut Mulyawan (2009) partisipasi masyarakat yaitu semua warga masyarakat mempunyai suara dalam pengambilan keputusan, baik secara langsung maupun melalui lembaga-lembaga perwakilan sah yang mewakili kepentingan mereka. Achmadi dalam Coryanata (2007) menyebutkan bahwa partisipasi masyarakat merupakan kunci sukses dari pelaksanaan otonomi daerah karena dalam partisipasi menyangkut aspek pengawasan dan aspirasi.

Berdasarkan beberapa definisi partisipasi diatas, dapat disimpulkan bahwa partisipasi masyarakat dalam urusan pemda sangat dibutuhkan guna memberikan saran agar kebijakan yang dikeluarkan nantinya tidak merugikan masyarakat mengingat kinerja organisasi publik selama ini dinilai masih kurang.

f. Keadilan

sebagai $\begin{gathered}\text { Keadilan dapat diartikan } \\ \text { bentuk kemampuan }\end{gathered}$ pemrintah daerah dalam memenuhi kesejahteraan kepada pegawainya berkaitan dengan hak dan kewajibannya. Kumorotomo dalam Mulyawan (2009) berpendapat bahwa keadilan mempertanyaan distribusi dan alokasi layanan yang diselenggarakan oleh organisasi pelayanan publik.

Prinsip keadilan merupakan prinsip yang harus dipenuhi agar tidak terjadi kecemburuan sosial dalam lingkungan internal pemerintahan daerah. Selain itu, keadilan juga harus diterapkan kepada masyarakat dalam pemenuhan kebutuhan masyarakat, tanpa memandang status sosial.

g. Responsibilitas

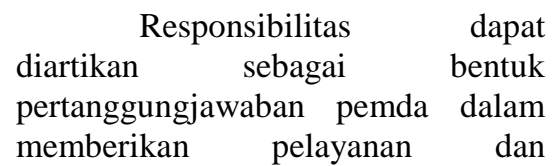
memberikan pelayanan dan Mulyawan (2009) menyatakan bahwa resposivititas adalah kemampuan organisasi untuk mengenali kebutuhan masyarakat menyusun agenda dan prioritas pelayanan dan mengembangkan program-program pelayanan publik sesuai dengan kebutuhan dan aspirasi masyarakat. Pratolo

(2010)

mengungkapkan

bahwa pertanggungjawaban

(responsiveness) adalah bentuk upaya pemerintah melaksanakan kewajibannya terkait dengan penjelasan mengenai kinerja yang disampaikannya kepada publik. Pemda diharapkan dapat melayani masyarakat sesuai standar pelayanan minimal pemda sehingga kualitas pelayanan pemda dapat dikatakan baik. Konsep pelayanan pada sektor publik dan sektor swasta intinya sama, masing-masing menginginkan respon yang positif dari customernya berkaitan dengan kualitas pelayanan yang diberikan.

\section{h. Kinerja Pemrintah Daerah}

Kinerja adalah prestasi kerja individu atau kelompok dalam kurun waktu tertentu. Menurut Wati dkk. (2010) mengungkapkan Kinerja (performance) adalah gambaran mengenai tingkat pencapaian pelaksanaan suatu kegiatan/program/kebijakan dalam mewujudkan sasaran, tujuan, misi dan visi organisasi yang tertuang dalam strategic planning suatu organisasi. Kinerja adalah pencapaian suatu tujuan dari suatu kegiatan atau pekerjaan tertentu untuk mencapai tujuan perusahaan yang diukur dengan standar (Pratolo, 2007). Kinerja sendiri dibagi menjadi dua, yaitu kinerja pribadi dan kelompok (organisasi). Kinerja organisasi kemudia juga dibagi mendajdi dua, yaitu kinerja finansial dan kinerja non 
finansial. Informasi yang digunakan dalam mengukur kinerja non keuangan adalah informasi yang disajikan tidak dalam satuan uang atau rupiah (non financial information) namun dengan satuan ukur non keuangan (Kaplan \& Atkinson dalam Pratolo, 2007) dan informasi yang digunakan dalam mengukur kinerja keuangan adalah informasi keuangan (financial information), yaitu informasi akuntansi manajemen dan informasi akuntansi keuangan seperti laba sebelum pajak, tingkat pengembalian investasi, dan sebagainya (Pratolo, 2007).

i. Indikator Kinerja

Indikator kinerja adalah ukuran kuantitatif dan kualitatif yang menggambarkan tingkat pencapaian sasaran atau tujuan yang telah ditetapkan. (Garnita, 2008). Indikator kinerja meliputi banyak hal, namun yang sering digunakan untuk mengukur kinerja sebuah organisasi yaitu dengan melihat indikator masukan, keluaran, hasil, manfaat, dan dampak dari suatu program kerja organisasi.

7. Penelitian terdahulu

a. Penelitian Mulyawan (2009)

Penelitian Mulyawan (2009) berjudul

"Pengaruh Pelaksanaan Good Governance terhadap Kinerja Organisasi". Obyek penelitian yang digunakan adalah Dinas Kesejahteraan Sosial Kota Palembang yang melibatkan 65 pegawai. Penelitian Mulyawan (2009) bertujuan menguji pengaruh prinsip good government governance terhadap kinerja organisasi. Prinsip good government governance yang digunakan pada penelitian Mulyawan (2009) adalah partisipasi masyarakat, tegaknya supremasi hukum, transparansi, kesetaraan, efektivitas dan efisiensi, akuntabilitas, dan visi strategis. Hasil penelitian yang dilakukan Mulyawan (2009)

menunjukkan bahwa prinsip good government governance secara bersama-sama (simultan) berpengaruh positif dan signifikan terhadap kinerja organisasi.

b. Penelitian Yusuf (2009)

Penelitian Yusuf (2009) berjudul "Pengaruh Pelaksanaan Good Governance terhadap Kinerja Pemerintah Daerah Kota Bandung". Obyek penelitian yang digunakan adalah Pemerintah Daerah Kota Bandung. Penelitian Yusuf (2009) bertujuan menguji pengaruh prinsip good government governance terhadap kinerja instansi pemerintah. Prinsip good government governance yang digunakan pada penelitian Yusuf (2009) adalah participation, rule of law, transparancy, responsiveness, consensus orientation, equity, effectiveness dan efficiency, accountability, dan strategi vision. Hasil penelitian yang dilakukan Yusuf (2009) menunjukkan bahwa prinsip good government governance secara parsial (individu) masing-masing berpengaruh positif dan signifikan terhadap kinerja organisasi, mulai dari participation, rule of law, transparancy, responsiveness, consensus orientation, equity, effectiveness dan efficiency, accountability, hingga strategi vision.

c. Penelitian Pratolo (2010)

Penelitian Pratolo (2010) berjudul "Peran Good Government Governance untuk Mewujudkan Kinerja Pemerintah Daerah dan Kepuasan Masyarakat di Era Otonomi Daerah dalam Menghadapi Tantangan Global". Obyek penelitian yang digunakan adalah Kabupaten dan Kota se DIY yang melibatkan pegawai SKPD dan masyarakat 
sekitar. Penelitian Pratolo (2010) bertujuan menguji pengaruh prinsip good government governance terhadap kinerja pemerintah daerah. Prinsip good government governance yang digunakan pada penelitian Pratolo (2010) adalah transparansi, akuntabilitas, pertanggungjawaban, keadilan, dan kemandirian. Hasil penelitian yang dilakukan Pratolo (2010) menunjukkan bahwa prinsip akuntabilitas dan independensi tidak berpengaruh terhadap kinerja pemerintah daerah. Sedangkan prinsip transparansi, responsibilitas, dan fairness berpengaruh positif dan signifikan terhadap kinerja pemerintah daerah.

8. Penurunan Hipotesis

a. Prinsip Transparansi

Transparansi adalah salah satu prinsip dalam good government governance. Prinsip transparansi mengharuskan suatu pemerintahan atau organisasi mengungkapkan program kegiatannya secara terbuka kepada para stakeholdernya. Dalam hal ini pemerintah dituntut menerapkan prinsip transparansi dalam pemerintahannya, baik transparan dalam hal laporan keuangan, program kegiatan, pelayanan, visi dan misi, dan lain sebagainya kepada masyarakat.

$$
\text { Melalui }
$$

transparansi

penyelenggaraan pemerintah, masyarakat diberikan kesempatan untuk mengetahui apa-apa yang terjadi dalam pemerintahan, termasuk diantaranya kebijakan yang akan atau telah diambil oleh pemerintah, serta implementasinya. Adanya keterbukaan dalam penyelenggaraan urusan publik akan memudahkan pengawasan terhadap jalannya pemerintahan. Pengawasan dari masyarakat dapat mencegah terjadinya mis-alokasi sumber daya maupun pelanggaran dalam kegiatan pemerintah seperti korupsi (CUI-ITB dalam Martha, 2014).
Transparansi yang dilakukan pemerintah akan mendorong kinerja pemerintah bekerja dengan baik dalam pelaksanaan program-program pemerintah serta dalam pengambilan keputusan publik (Martha, 2014).

Seperti yang diungkapkan Pratolo (2010) bahwa apabila informasi disampaikan secara transparan kepada masyarakat, maka akan menimbulkan suatu kepercayaan yang tinggi dari masyarakat terhadap pemerintah sehingga akan menimbulkan kinerja pemerintah yang lebi baik.

Hal ini didukung oleh penelitian yang telah dilakukan oleh Martha (2014) dan Pratolo (2010) yang meneliti tentang pengaruh transparansi terhadap kinerja instansi pemerintah. Hasil penelitian keduanya mengungkapkan bahwa transparansi berpengaruh signifikan terhadap instansi pemerintah.

Maka berdasarkan penjabaran diatas, diturunkan hipotesis sebagai berikut:

$\mathrm{H}_{1}$ : Prinsip Transparansi berpengaruh positif terhadap Kinerja Pemerintah Daerah.

b. Prinsip Akuntabilitas

Prinsip Akuntabilitas selalu berikatan erat dengan adanya prinsip transparansi. Berbicara mengenai prinsip akuntabilitas juga berkaitan dengan penyajian laporan akuntabilitas kinerja instansi pemerintah pada akhir periode. Prinsip akuntabilitas menjelaskan bagaimana suatu unit harus dapat mempertanggungjawabkan hasil dari program pemerintahan yang telah dijalankan dan kebijakan-kebijakan yang telah dirumuskan kepada stakeholdernya.

Widodo dalam Martha (2014) mengungkapkan bahwa akuntabilitas merupakan persyaratan mendasar untuk mencegah penyalahgunaan kewenangan yang didelegasikan dan menjamin kewenangan tadi diarahkan pada pencapaian-pencapaian tujuan nasional yang diterima secara luas dengan tingkat efisiensi, efektifitas, kejujuran. Pelaku kebijakan publik 
dalam hal ini adalah instansi peerintah harus dapat bertanggungjawab terhadap apa yang menjadi sikap, perilaku, dan sepak terjangnya kepada publik dalam menjalankan tugas, fungsi dan kewenangan yang diberikan kepadanya.

Akibat dari kurangnya penerapan prinsip akuntabilitas pada pemerintah daerah diantaranya para pemimpin daerah yang tidak menepati janji yang diucapkan pada saat dirinya mencalonkan diri, terdapat kebijakan-kebijakan yang menyengsarakan dan merugikan masyarakat, terutama masyarakat kecil. Itu semua dapat terjadi karena masyarakat kurang peduli dan menagih janji-janji pemimpin daerah, karena pemenuhan janji adalah salah satu bentuk akuntabilitas pemerintah terhadap masyarakat.

Martha (2014) memberikan penjelasan tambahan bahwa akuntabilitas merupakan suatu unsur yang terpenting untuk mewujudkan suatu sistem pemerintahan yang bersih dan baik, dengan adanya akuntabilitas tentunya akan mendorong kinerja instansi pemerintah bekerja dengan optimal dalam menjalankan program-program pemerintah serta dalam pengambilan kebijakan publik, karena instansi pemerintah harus mempertanggungjawabkan hasil kinerjanya kepada publik.

Hal serupa juga didukung oleh penjabaran dari Pratolo (2010) bahwa apabila pertanggungjawaban pejabat publik terhadap masyarakat diterapkan dengan baik oleh pemerintah kepada masyarakat, maka akan menimbulkan suatu kepercayaan yang tinggi dari masyarakat sehingga akan menimbulkan kinerja pemerintah menjadi lebih baik.

Hal ini didukung hasil penelitian yang dilakukan oleh Garnita (2008) dan Martha (2014) yang menunjukkan bahwa akuntabilitas berpengaruh signifikan terhadap kinerja instansi pemerintah.
Berdasarkan penjabaran diatas, maka diturunkan hipotesis sebagai berikut:

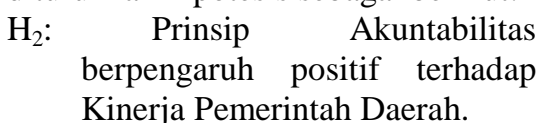

c. Prinsip Partisipasi Masyarakat

Masyarakat merupakan stakeholder bagi pemerintah daerah, pemerintah daerah dianjurkan dapat melibatkan masyarakat dalam sebuah pemecahan masalah yang dihadapi pemerintah daerah. Keterlibatan masyarakat diharapkan mampu memberikan saran-saran demi kemajuan kinerja pemda. Achmadi dalam Coryanata (2007) menyebutkan bahwa partisipasi masyarakat merupakan kunci sukses dari pelaksanaan otonomi daerah karena dalam partisipasi menyangkut aspek pengawasan dan aspirasi.

Prinsip partisipasi merupakan kunci dalam sebuah organisasi, baik swasta maupun publik. Partisipasi mengedepankan keterlibatan stakeholder dalam berbagai urusan organisasi, dalam solusi pemecahan masalah ataupun dalam hal lainnya yang bertujuan untuk memajukan kinerja organisasi.

Itu berarti, semakin aktif masyarakat dalam proses penyelenggaraan pemerintahan maka akan mendukung semakin suksesnya pelakasanaan otonomi pada suatu daerah, dan ketika otonomi di suatu daerah dapat tercapai maka hal itu akan mendorong pemda daerah tersebut untuk mengupayakan kinerja yang lebih baik.

Penelitian tentang pengaruh good governance terhadap kinerja instansi pemerintah pernah dilakukan oleh Ambarwati dkk. (2013), dimana salah satu prinsip good dovernance termasuk partisipasi masyarakat didalamnya.

Berdasarkan pemaparan diatas, maka dapat diturunkan hipotesis bahwa:

$\mathrm{H}_{3}$ : Prinsip Partisipasi Masyarakat berpengaruh positif terhadap Kinerja Pemerintah Daerah.

d. Prinsip Keadilan 
Keadilan dapat diartikan sebagai bentuk kemampuan pemda dalam memenuhi kesejahteraan kepada pegawainya berkaitan dengan hak dan kewajibannya. Pratolo (2010) mengungkapkan penjabaran keadilan sebagai keserataan di dalam memenuhi hak-hak stakeholder yang timbul berdasarkan perjanjian dan peraturan perundang-undangan yang berlaku.

Apabila prinsip keadilan diterapkan dengan baik oleh pemerintah, maka kepercayaan masyarakat akan lebih tinggi terhadap pemerintah sehingga akan menimbulkan kinerja pemerintah menjadi lebih baik (Pratolo, 2010). Hal ini didukung oleh penelitian yang dilakukan oleh Pratolo (2010) yang menyatakan bahwa prinsip keadilan berpengaruh terhadap kinerja pemerintah daerah.

\section{$\mathrm{H}_{4}$ : Prinsip Keadilan berpengaruh positif terhadap kinerja Pemerintah Daerah.}

e. Prinsip Responsibilitas

Mulyawan

menyatakan bahwa responsivititas adalah kemampuan organisasi untuk mengenali kebutuhan masyarakat menyusun agenda dan prioritas pelayanan dan mengembangkan program-program pelayanan publik sesuai dengan kebutuhan dan aspirasi masyarakat. Pemda harus melayani dan memenuhi kebutuhan masyarakat secara maksimal dan berkualitas. Kualitas layanan pemda harus memenuhi standarnya agar masyarakat dapat merasakan kepuasan atas pelayanan pemda.

Kualitas pelayanan pemda menjadi kriteria utama bagi masyarakat sekitar dalam memberikan penilaian atas kinerja pemda. Semakin baik pelayanan yang dilakukan pemda terhadap masyarakatnya, maka masyarakat akan menilai kinerja pemda tersebut bertambah baik pula, begitupun sebaliknya. Masyarakat menginginkan pelayanan yang maksimal dari pemda, baik mulai dari infrastrukturnya sampai dengan sikap karyawan dalam memberikan pelayanan. Sudah seharusnya pemda menampung keluhan dan aspirasi dari masyarakat kemudian menindaklanjutinya langsung. Pemda dituntut untuk dapat memberikan solusi atas masalah yang dihadapi masyarakat, bukannya malah merugikan masyarakat.

Pratolo (2010) menyatakan bahwa apabila pemerintah lebih tanggap terhadap persoalan-persoalan yang dihadapi masyarakat, maka kepercayaan masyarakat akan lebih tinggi terhadap pemerintah sehingga menimbulkan kinerja pemerinah yang lebih baik.

Penelitian sejenis sudah pernah dilakukan oleh Pratolo (2010) yang menyatakan bahwa prinsip responsibilitas berpengaruh terhadap kinerja instansi pemerintah.

Dari penjabaran diatas, maka dapat diturunkan hipotesis sebagai berikut:

$\mathrm{H}_{5}$ : Prinsip Responsibilitas berpengaruh positif terhadap Kinerja Pemerintah Daerah.

\section{METODE PENELITIAN}

Penelitian ini merupakan penelitian explanatori dengan pendekatan kuantitatif. Obyek penelitian pada penelitian ini adalah pemerintah Kabupaten Gunungkidul, yaitu meliputi Badan dan Dinas. Adapun subyek penelitiannya adalah pegawai pada Badan dan Dinas di Kabupaten Gunungkidul.

Jenis data yang digunakan meliputi data primer dan data sekunder. Data primer pada penelitian ini berupa kuisioner, sedangkan data sekunder berasal dari berbagai sumber berupa jurnal penelitian, buku, media massa yang berkaitan dengan judul peneliti untuk dijadikan sebagai pustaka. Metode pengumpulan data dalam penelitian ini adalah dengan melakukan survey lapangan, yaitu mendatangi semua Badan dan Dinas di Kabupaten Gunung Kidul untuk dibagikan kuisioner. Perhitungan jumlah sampel pada penelitian ini menggunakan formula perhitungan Slovin dengan menggunakan nilai 
kelonggaran $\left(\mathrm{e}^{2}\right)$ sebesar 10\% (Sinaga, 2011).

Formulanya ialah:

$$
\mathrm{n}=\frac{N}{1+W \cdot \mathrm{\epsilon}^{2}}
$$

Keterangan:

$$
\begin{array}{ll}
\mathrm{N} & =\text { jumlah sample } \\
\mathrm{N} & =\text { jumlah populasi } \\
\mathrm{e}^{2} & =\text { nilai kelonggaran ketidaktelitian }
\end{array}
$$

Alat analisis menggunakan regresi berganda dengan bantuan SPSS 15 for windows. Uji yang dilakukan pada penelitian ini meliputi statistik deskriptif,

\section{Tabel 4.1}

Tabel Jenis Responden

\begin{tabular}{|l|c|c|}
\hline Pegawai Badan atau Dinas & 95 & $95 \%$ \\
\hline Masyarakat & 5 & $5 \%$ \\
\hline Total Responden & 100 & $100 \%$ \\
\hline
\end{tabular}

Semua data pada penelitian ini adalah reliable, karena nilai cronbach alpha dari masing-masing variabel dalam penelitian uji kualitas data, uji asumsi klasik, dan uji hipotesis.

\section{HASIL PENELITIAN DAN PEMBAHASAN}

Jumlah populasi sebanyak 1900 orang, maka dengan melalui perhitungan rumus Slovin sampling method, maka diperoleh sampel pada penelitian ini adalah sebanyak 100 responden, itu meliputi pegawai Badan atau Dinas di Kabupaten Gunungkidul dan masyarakat sekitar. Adapun proyeksi jumlah responden disajikan dalam tabel berikut: ini menunjukkan bahwa nilainya > 0,6 seperti yang diisyaratkan.

Tabel 4.2

Hasil Uji Validitas

\begin{tabular}{|l|c|c|c|}
\hline Variabel & Item & faktor loading & Kriteria \\
\hline Transparansi & Q1 & 0,765 & Valid \\
\hline & Q2 & 0,717 & Valid \\
\hline & Q3 & 0,806 & Valid \\
\hline & Q4 & 0,787 & Valid \\
\hline Akuntabilitas & Q5 & 0,708 & Valid \\
\hline & Q6 & 0,645 & Valid \\
\hline & Q7 & 0,823 & Valid \\
\hline & Q8 & 0,831 & Valid \\
\hline & Q9 & 0,693 & Valid \\
\hline Partisipasi Masyarakat & Q10 & 0,688 & Valid \\
\hline & Q11 & 0,798 & Valid \\
\hline & Q12 & 0,718 & Valid \\
\hline & Q13 & 0,621 & Valid \\
\hline & Q14 & 0,822 & Valid \\
\hline Keadilan & Q15 & 0,720 & Valid \\
\hline & Q16 & 0,835 & Valid \\
\hline & Q17 & 0,827 & Valid \\
\hline & Q18 & 0,835 & Valid \\
\hline & Q19 & 0,853 & Valid \\
\hline & Q20 & 0,848 & Valid \\
\hline
\end{tabular}




\begin{tabular}{|l|c|c|c|} 
Responsibilitas & Q21 & 0,864 & Valid \\
\hline & Q22 & 0,889 & Valid \\
\hline & Q23 & 0,838 & Valid \\
\hline & Q24 & 0,799 & Valid \\
\hline & Q25 & 0,722 & Valid \\
\hline Kinerja Pemda & Q26 & 0,873 & Valid \\
\hline & Q27 & 0,706 & Valid \\
\hline & Q28 & 0,876 & Valid \\
\hline & Q29 & 0,850 & Valid \\
\hline & Q30 & 0,855 & Valid \\
\hline
\end{tabular}

Semua data pada penelitian ini adalah valid, karena nilai faktor loading dari masing-masing butir pertanyaan dalam penelitian ini menunjukkan bahwa nilainya

$>0,4$ seperti yang diisyaratkan

Tabel 4.3

Tabel Uji Validitas

\begin{tabular}{|l|c|}
\hline \multicolumn{1}{|c|}{ Variabel } & Cronbach Alpha \\
\hline Transparansi & 0,807 \\
\hline Akuntabilitas & 0,798 \\
\hline Partisipasi Masyarakat & 0,784 \\
\hline Keadilan & 0,885 \\
\hline Responsibilitas & 0,877 \\
\hline Kinerja Pemda & 0,889 \\
\hline
\end{tabular}

Uji Asumsi klasik pada penelitian ini terdiri dari normalitas, multikolinieritas, dan heteroskedastisitas. Model regresi pada penelitian ini menunjukkan bahwa

tidak terjadi multikolinieritas, model regresi homoskedastisitas,dan model berdistribusi nornal. Hal tersebut ditunjukkan dalam tabel dibawah ini:

Tabel 4.4

Hasil Uji Normalitas

\begin{tabular}{|l|c|c|}
\hline One Kolomogorov-smirnov & assymp sig (2-tailed) & Keterangan \\
\hline Unstandardized Residual & 0,225 & Data Normal \\
\hline
\end{tabular}

Dari tabel diatas dapat dilihat nilai assymp sig (2-tailed) pada tabel One Kolmogorovnilai assymp sig(2-tailed) > alpha $(0,05)$, jadi data dikatakan berdistribusi normal.

Tabel 4.5

Hasil uji Multikolinieritas

\begin{tabular}{|l|c|c|}
\hline \multicolumn{1}{|c|}{ Variabel } & Tolerance & VIF \\
\hline Transparansi & 0,442 & 2,261 \\
\hline Akuntabilitas & 0,263 & 3,809 \\
\hline Partisipasi Masyarakat & 0,542 & 1,843 \\
\hline Keadilan & 0,444 & 2,251 \\
\hline
\end{tabular}




\begin{tabular}{|l|r|r|} 
Responsibilitas & $0,309 \quad 3,233$ \\
\hline
\end{tabular}

Dari tabel 4.5 di atas, terlihat bahwa tidak ada variabel yang memiliki nilai VIF lebih besar dari 10 dan nilai tolerance yang lebih kecil dari $10 \%$, yang berarti bahwa tidak terdapat korelasi antar variabel bebas dinyatakan tidak terdapat multikolinearitas antar variabel bebas dalam model regresi penelitian ini.

Tabel 4.6

Hasil Uji Heteroskedastisitas

\begin{tabular}{|l|c|l|}
\hline \multicolumn{1}{|c|}{ Variabel } & sig & \multicolumn{1}{c|}{ Kesimpulan } \\
\hline Transparansi & 0,544 & Homoskesdastisitas \\
\hline Akuntabilitas & 0,176 & Homoskesdastisitas \\
\hline Partisipasi Masyarakat & 0,256 & Homoskesdastisitas \\
\hline Keadilan & 0,096 & Homoskesdastisitas \\
\hline Responsibilitas & 0,667 & Homoskesdastisitas \\
\hline
\end{tabular}

Hasil penelitian didapatkan nilai signifikansi variabel transparansi $\left(\mathrm{X}_{1}\right)$ sebesar 0,544 >0,05, variabel akuntabilitas $\left(\mathrm{X}_{2}\right)$ sebesar $0,176>0,05$, variabel partisipasi masyarakat $\left(\mathrm{X}_{3}\right)$ sebesar 0,256 $>0,05$, variabel keadilan $\left(\mathrm{X}_{4}\right)$ sebesar $0,096>0,05$, variabel responsibilitas $\left(\mathrm{X}_{5}\right)$ sebesar $0,667>0,05$.
Kelima variabel diatas menunjukkan bahwa tidak adanya heteroskedatisitas, maka dari itu model regresi dapat diuji dengan analisa regresi melalui sebuah persamaan.

Hasil penelitian ini mengungkapkan bahwa:

Tabel 4.7

Hasil Uji Regresi Berganda

\begin{tabular}{|l|c|c|c|l|}
\hline \multicolumn{1}{|c|}{ Variabel } & $\begin{array}{c}\text { Koefisien } \\
\text { Regresi }\end{array}$ & t hitung & sig & \multicolumn{1}{|c|}{ Keterangan } \\
\hline Konstanta & 4,105 & 2,244 & 0,027 & \\
\hline Transparansi & 0,022 & 0,203 & 0,840 & Hipotesis Ditolak \\
\hline Akuntabilitas & 0,063 & 0,410 & 0,683 & HipotesisDitolak \\
\hline Partisipasi Masyarakat & 0,017 & 0,185 & 0,854 & Hipotesis Ditolak \\
\hline Keadilan & 0,369 & 4,049 & 0,000 & Hipotesis Diterima \\
\hline Responsibilitas & 0,363 & 3,051 & 0,003 & Hipotesis Diterima \\
\hline Adjusted $\mathrm{R}^{2}$ & 0,558 & & & \\
\hline
\end{tabular}

Tabel diatas menggambarkan hasil estimasi persamaan Regresi Linear Berganda dengan program SPSS 15 for windows, maka dapat disimpulkan persamaan regresi linear berganda dalam penelitian ini adalah sebagai berikut :

$$
Y=4,105+0,022 X_{1}+0,063 X_{2}+0,017 X_{3}
$$$$
+0,369 X_{4}+0,363 X_{5}
$$

Dengan demikian model regresi penelitian menjelaskan bahwa:

- Variabel Transparansi $\left(\mathrm{X}_{1}\right)$ berpengaruh positif terhadap Kinerja Pemda (Y). Terlihat pada tabel bahwa variabel transparansi mempengaruhi Kinerja Pemda sebesar 2,2\%.

- Variabel Akuntabilitas $\left(\mathrm{X}_{2}\right)$ berpengaruh positif terhadap Kinerja Pemda (Y). 
Terlihat pada tabel bahwa variabel akuntabilitas mempengaruhi Kinerja Pemda sebesar 6,3\%.

- Variabel Partisipasi Masyarakat $\left(\mathrm{X}_{3}\right)$ berpengaruh negatif terhadap Kinerja Pemda (Y). Terlihat pada tabel bahwa variabel partisipasi masyarakat mempengaruhi Kinerja Pemda hanya sebesar $1,7 \%$.

- Variabel Keadilan $\left(\mathrm{X}_{4}\right)$ berpengaruh positif terhadap Kinerja Pemda (Y). Terlihat pada tabel bahwa variabel keadilan mempengaruhi Kinerja Pemda sebesar $36,9 \%$.

- Variabel Responsibilitas $\left(\mathrm{X}_{5}\right)$ berpengaruh positif terhadap Kinerja Pemda (Y). Terlihat pada tabel bahwa variabel responsibilitas mempengaruhi Kinerja Pemda sebesar 36,3\%.

\section{a. Uji Hipotesis Pertama $\left(\mathrm{H}_{1}\right)$}

Nilai thitung pada variabel Transparansi $\left(\mathrm{X}_{1}\right)$ adalah sebesar 0,203 dan nilai signifikansi sebesar 0,840 . Karena $\mathrm{t}_{\text {hitung }}(0,203)<\mathrm{t}_{\text {tabel }}(1,66)$ dan nilai signifikansi $(0,840)>$ alpha $(0,05)$ maka Hipotesis ditolak. Dengan demikian dapat dikatakan bahwa pada penelitian ini variabel transparansi tidak berpengaruh terhadap kinerja pemda. Hasil penelitian ini menunjukkan bahwa penerapan prinsip transparansi tidak menentukan pemda dalam memajukan kinerjanya. Ketika suatu pemda menerapkan prinsip transparansi secara optimal pada pemerintahannya, itu tidak serta merta akan membuat masyarakat menaruh kepercayaan tinggi pada pemda tersebut. Hal ini disebabkan oleh sesuatu yang sudah melekat pada benak masyarakat tentang reputasi pemda tersebut, misalnya pemberitaan tentang banyaknya kasus korupsi di Indonesia yang terjadi pemda di Indonesia. Hal itu tentu akan sulit merubah pandangan masyarakat akan kinerja sebuah pemda yang dimana pemda tersebut reputasinya sudah jelek dimata masyarakat. Hal ini juga terlihat dari pemda yang masih enggan mempublikasikan laporan keuangan pada situs pemda maupun media massa, padahal sudah seharusnya masyarakat dan stakeholder lainnya dapat melihat dan mempelajari laporan keuangan pemda untuk dijadikan penilaian terhadap kinerja pemda agar menjadi lebih baik. Alasan lainnya adalah pemda masih enggan mempublikasikan rencana atau target program kerja kepada masyarakat, padahal informasi seperti ini masyarakat perlu untuk mengetahuinya agar masyarakat nantinya dapat melakukan pengawasan akan program kerja yang dilaksanakan pemda. Pemda seharusnya menyampaikan atau mempublikasikan rencana program kerja yang akan di jalankan pemerintah daerah kepada masyarakat, hal ini berarti menunjukkan bahwa pemda bersifat terbuka kepada masyarakat. Hasil penelitian ini sejalan dengan hasil penelitian yang di tuliskan oleh Ambarwati dkk. (2013) bahwa penerapan prinsip good corporate governance tidak berpengaruh terhadap kinerja instansi pemerintah, dimana didalamnya terdapat prinsip transparansi.

\section{b. Uji Hipotesis Kedua $\left(\mathrm{H}_{2}\right)$}

Nilai thitung pada variabel Akuntabilitas $\left(\mathrm{X}_{2}\right)$ adalah sebesar 0,410 dan nilai signifikansi sebesar 0,683. Karena $t_{\text {hitung }}(0,410)<t_{\text {tabel }}(1,66)$ dan nilai signifikansi $(0,683)>$ alpha $(0,05)$ maka Hipotesis ditolak. Dengan demikian dapat dikatakan bahwa pada penelitian ini variabel akuntabilitas tidak berpengaruh terhadap kinerja pemda. Hasil penelitian ini menunjukkan bahwa penerapan prinsip akuntabilitas tidak menentukan pemda dalam memajukan kinerjanya. Saat pemda menerapkan prinsip akuntabilitas pada lingkungannya, ini tidak serta merta akan menumbuhkan kepercayaan tinggi pada masyarakat. Hal ini dikarenakan beberapa alasan, diantaranya tidak ditepatinya janji kepala daerah akan program kerja yang ditawarkan saat mencalonkan diri, kebijakan/peraturan yang tidak memenuhi kebutuhan masyarakat, dan lain sebagainya. Pemenuhan janji dan perumusan kebijakan yang memihak rakyat merupakan sesuatu yang penting karena ini merupakan perwujudan 
akuntabilitas suatu pemda, dimana makna dari akuntabilitas adalah pertanggungjawaban. Hal ini juga terlihat dari pemda yang masih tidak mau mempublikasikan Laporan Akuntabilitas Kinerja Instansi Pemerintah (LAKIP) kepada masyarakat, padahal isi dari LAKIP menunjukkan jumlah rencana program kerja yang di targetkan oleh pemda dalam satu periode dan berapa jumlah program kerja yang terealisasi, dan masyarakat membutuhkan hal tersebut agar dapat melakukan penilaian terhadap kinerja pemda. Hasil penelitian ini sejalan dengan penelitian yang dilakukan oleh Suryo (2010) yang menunjukkan pengaruh bahwa akuntabilitas tidak berpengaruh terhadap kinerja pemerintah daerah, dengan nilai sig sebesar 0,229.

\section{c. Uji Hipotesis Ketiga $\left(\mathbf{H}_{3}\right)$}

Nilai thitung pada variabel Partisipasi Masyarakat $\left(\mathrm{X}_{3}\right)$ adalah sebesar 0,185 dan nilai signifikansi sebesar 0,854 . Karena $t_{\text {hitung }}(0,185)<\mathrm{t}_{\text {tabel }}(1,66)$ dan nilai signifikansi $(0,854)>$ alpha $(0,05)$ maka Hipotesis ditolak. Dengan demikian dapat dikatakan bahwa pada penelitian ini variabel tidak berpengaruh tidak berpengaruh terhadap kinerja pemda. Hasil penelitian ini menunjukkan bahwa penerapan prinsip partisipasi masyarakat tidak menentukan pemda dalam memajukan kinerjanya. Saat suatu pemda dapat menerapkan prinsip partisipasi masyarakat secara optimal pada pemerintahannya, belum tentu akan tercipta kinerja yang baik. Kinerja pemda digambarkan melalui terciptanya otonomi daerah suatu daerah, sedangkan otonomi daerah dipengaruhi oleh beberapa faktor. Achmadi dalam Coryanata (2007) menyebutkan bahwa partisipasi masyarakat merupakan kunci sukses dari pelaksanaan otonomi daerah karena dalam partisipasi menyangkut aspek pengawasan dan aspirasi. Akan tetapi, otonomi daerah juga dipengaruhi oleh beberapa faktor selain partisipasi masyarakat, diantaranya sumber daya alam, ketersediaan dana, sarana dan prasarana, serta manajemen pengelolaannya. Hal ini juga terlihat dari pemda yang masih tidak setuju untuk melibatkan masyarakat dalam perumusan kebijakan daerah dan rapat rutin pemda, padahal disini masyarakat mempunyai peranan penting untuk memajukan kinerja pemda kearah lebih baik dengan memberikan saran-saran kepada pemda untuk dijadikan pertimbangan dalam pengambilan keputusan maupun perumusan kebijakan. Ketika otonomi daerah tidak tercapai maka pemda tersebut tidak mempunyai dorongan untuk memperoleh kinerja yang lebih baik. Hasil penelitian ini sejalan dengan hasil penelitian yang di tuliskan oleh Ambarwati dkk. (2013) bahwa penerapan prinsip good corporate governance tidak berpengaruh terhadap kinerja instansi pemerintah, dimana didalamnya terdapat prinsip partisipasi masyarakat.

\section{d. Uji Hipotesis Keempat $\left(\mathbf{H}_{4}\right)$}

Nilai thitung pada variabel Keadilan $\left(\mathrm{X}_{4}\right)$ adalah sebesar 4,049 dan nilai signifikansi sebesar 0,000 . Karena $t_{\text {hitung }}$ $(4,049)>t_{\text {tabel }}(1,66)$ dan nilai signifikansi $(0,000)<$ alpha $(0,05)$ maka Hipotesis diterima. Dengan demikian dapat dikatakan bahwa pada penelitian ini variabel keadilan berpengaruh secara signifikan terhadap kinerja pemda. Hasil penelitian ini menunjukkan bahwa penerapan prinsip keadilan mempunyai peranan penting untuk memajukan kinerja pemda. Penerapan prinsip keadilan pada lingkungan pemda Kabupaten Gunungkidul sudahlah baik, hal ini terlihat dari perlakuan pemda Kabupaten Gunungkidul yang bersikap tegas terhadap pegawai pemda yang kurang disiplin atau menyalahgunakan wewenang. Saat keadilan dapat tercipta dilingkungan pemda, pegawai tidak akan berani melanggar peraturan yang yang telah ditetapkan di lingkungan pemda. Dengan demikian sedikitnya bentuk pelanggaran-pelanggaran pada lingkungan pemda maka dapat mengindikasikan bahwa kinerja pemda baik. Hasil penelitian ini sejalan 
dengan penelitian yang dilakukan oleh Suryo (2010) yang menunjukkan pengaruh keadilan terhadap kinerja pemda mempunyai nilai sig yaitu 0,001. Dengan demikian berarti bahwa nilai sig $(0,001)<$ alpha $(0,05)$.

\section{e. Uji Hipotesis Kelima $\left(\mathbf{H}_{5}\right)$}

Nilai thitung pada variabel Responsibilitas $\left(\mathrm{X}_{5}\right)$ adalah sebesar 3,051 dan nilai signifikansi sebesar 0,003. Karena $t_{\text {hitung }}(3,051)>t_{\text {tabel }}$ $(1,66)$ dan nilai signifikansi $(0,003)<$ alpha $(0,05)$ maka Hipotesis diterima. Dengan demikian dapat dikatakan bahwa pada penelitian ini variabel responsibilitas berpengaruh secara signifikan terhadap kinerja pemda. Hasil penelitian inimenujukkan bahwa penerapan prinsip responsibilitas mempunyai peranan penting untuk memajukan kinerja pemda. Penerapan prinsip responsibilitas pada lingkungan pemda Kabupaten Gunungkidul sudahlah baik, hal ini terlihat dari pemda Kabupaten Gunungkidul yang selalu memberikan pelayanan optimal terhadap masyarakat yang membutuhkan informasi materiil mengenai pemda maupun masyarakat yang menyampaikan keluhannya. Masyarakat akan memberikan kepercayaan yang tinggi karena pemda sudah dapat melayani dengan optimal dan tanggap atas keluhan masyarakat. Dengan demikian dapat dikatakan kinerja pemda tersebut sudah baik. Hasil penelitian ini sejalan dengan penelitian yang dilakukan oleh Suryo (2010) yang menunjukkan pengaruh responsibilitas terhadap kinerja pemda mempunyai nilai sig yaitu 0,045 . Dengan demikian berarti bahwa nilai $\operatorname{sig}(0,045)<$ alpha $(0,05)$.

Koefisien Determinasi (Adjusted $R^{2}$ ) menunjukkan nilai sebesar 0,558 dengan demikian dapat disimpulkan bahwa variabel-variabel independen dalam penelitian ini hanya mampu menjelaskan 55,8\% dari kinerja pemda yang merupakan variabel dependen dalam penelitian ini. Sedangkan sisanya yaitu $44,2 \%$ dijelaskan oleh variabel lain yang tidak termasuk dalam model penelitian ini.

\section{SIMPULAN DAN SARAN}

1. Kesimpulan

Data dalam penelitian adalah valid dan reliable, karena sudah memenuhi syarat yang ditentukan. Hasil yang diperoleh dalam penelitian ini menunjukkan bahwa prinsip transparansi, akuntabilitas, dan partisipasi masyarakat mempunyai pengaruh terhadap kinerja pemda namun tidak signifikan atau dapat dikatakan tidak berpengaruh terhadap kinerja pemda.Sedangkan variabel keadilan dan responsibilitas mempunyai pengaruh yang signifikan terhadap kinerja pemda.

Dalam penelitian ini peneliti meyimpulkan bahwa penerapan prinsip good government governance di pemerintah Kabupaten Gunungkidul masih terbilang kurang, terutama dalam hal transparansi, akuntabilitas, dan pertisipasi masyarakat. Terlihat bahwa pemda yang masih enggan mempublikasikan laporan keuangan pada situs pemda maupun media massa, pemda masih enggan mempublikasikan rencana atau target program kerja kepada masyarakat, pemda masih enggan mempublikasikan LAKIP, serta pemda juga masih tidak setuju atas keterlibatan masyarakat dalam perumusan kebijakan / peraturan daerah. Dari kesimpulan diatas, maka sudah seharusnya seluruh pemerintah daerah di Indonesia menerapkan prinsip lingkungannya agar kinerja untuk tahun berikutnya dapat meningkat.

\section{Saran}

Penelitian ini tentunya masih memiliki banyak kekurangan, sehingga disini peneliti menyarankan agar peneliti selanjutnya untuk:

a. Mengganti tempat observasi penelitian dan melibatkan lebih banyak SKPD didalamnya. Peneliti selanjutnya diharapkan lebih memilih Kabupaten lain yang kriteria kinerjanya masih terbilang 
memuaskan, seperti misalnya kabupaten hasil pemekaran. Hal ini bertujuan agar dapat dijadikan evaluasi kinerja bagi daerah penelitian selanjutnya.

b. Melibatkan lebih banyak responden masyarakat agar lebih bisa dijadikan pengontrol atas penilaian penerapan Good Government Governance yang diberikan pegawai pemda.

c. Menambah variabel lainnya yang berpengaruh terhadap kinerja dan termasuk dalam prinsip Good Government Governance, misalnya seperti Kemandirian, Efektivitas dan Efisiensi, dan lain-lain.

\section{Daftar Pustaka}

Ambarwati, W., Suyono, E., Pratiwi, U., 2013, "Analisis Pengaruh Penerapan Prinsip-prinsip Good Corporate Governance dan Komitmen Organisasi terhadap Kinerja Aparatur Pemerintahan”, Jurnal.

Coryanata, I., 2007, “Akuntabilitas, Partisipasi Masyarakat, dan Transparansi Kebijakan Publik sebagai Pemoderating Hubungan Pengetahuan Dewan tentang Anggaran dan Pengawasan Keuangan daerah (APBD)", Proceding SNA X, 2007.

Garnita, N., 2008, "Pengaruh Akuntabilitas terhadap Kinerja Instansi Pemerintah Daerah", Universitas Widyatama, 2008, Skripsi.

Hapsari, I., 2011, "Hubungan antara Good Corporate Governance dan Transparansi terhadap Kinerja Perusahaan", Universitas Diponegoro, 2011, Skripsi.
Hardiwinoto, 2004, "Korelasi Timbal Balik antara Good Government dengan Good Corporate Governance menuju Pertumbuhan yang Dinamis", Universitas Muhammadiyah Semarang, 2004.

IHPS BPK RI semester I Tahun 2014, www.bpkri.go.id, Diakses tanggal 25 Desember 2014 pk 20.00 WIB.

Martha, W., 2014, "Pengaruh Transparansi dan Akuntabilitas terhadap Kinerja Instansi Pemerintah pada Dinas Kota Bandung", Universitas Widyatama, Skripsi.

Mulyawan, B., 2009, "Pengaruh Good Governance terhadap Kinerja Organisasi", Universitas Sumatra Utara, 2009, Skripsi.

Peraturan Pemerintah No. 71 Tahun 2010 tentang Standar Akuntansi Pemerintah.

Pratolo, S., 2007, "Good Corporate Governance dan Kinerja BUMN di Indonesia: Aspek Audit Manajemen dan Pengendalian Intern sebagai Variabel Eksogen serta tinjauannya pada Perusahaan", Proceding SNA X, 2007.

, 2010, "Peran Good Government Governance untuk Mewujudkan Kinerja Pemerintah Daerah dan Kepuasan Masyarakat di Era Otonomi Daerah dalam Menghadapi Tantangan Global", Simposium Riset Ekonomi IV, 2010.

Rahadian, A. H., 2008, "Mewujudkan Good Governance Melalui Pelayanan Publik", 2008.

Ridha, M. A., dan Basuki, H., 2012, "Pengaruh Tekanan Eksternal, Ketidakpastian Lingkungan, dan Komitmen Manajemen terhadap Penerapan Transparansi Laporan Keuangan", Proceding SNA XV, 2012. 
Rustiarini, N. W., 2010, "Pengaruh Corporate Governance pada Hubungan Corporate Social Responsibility dan Nilai Perusahaan", Proceding SNA XIII, 2010.

Santoso, U. dan Pambulum Y. J., 2008, "Pengaruh Penerapan Akuntansi Sektor Publik terhadap Akuntabilitas Kinerja Instansi Pemerintah dalam Mencegah Fraud, 2008.

Sari, D., 2013, "Pengaruh Sistem Pengendalian Intern Pemerintah, Implementasi Standar Akuntansi Pemerintahan, Penyelesaian Temuan Audit Terhadap Penerapan Prinsip-Prinsip Tata Kelola Pemerintahan yang Baik", Proceding SNA XVI sesi 1, 2013, hal. 1007.

Sinaga, Y. F., 2011, “Analisis Faktor-Faktor yang Mempengaruhi Pelaporan Keuangan di Internet secara sukarela oleh Pemerintah Daerah", Universitas Diponegoro, 2011, Skripsi.
TAP MPR RI No. XI/ MPR/ 1999 tentang Penyelenggara Negara yang Bersih dan Bebas KKN.

Trisnaningsih, S., 2007, "Independensi Auditor dan Komitmen Organisasi sebagai mediasi Pengaruh Pemahaman Good Governanc, Gaya Kepemimpinan, dan Budaya Organisasi terhadap Kinerja Auditor", Proceding SNA X, 2007.

Undang-Undang No. 28 Tahun 1999 tentang Penyelenggara Negara yang bersih dan bebas Korupsi, Kolusi, dan Nepotisme.

Wati, E., Lismawati, Nila, A., 2010, "Pengaruh Independensi, Gaya Kepemimpinan, Komitmen Organisasi, dan Pemahaman Good Governance terhadap Kinerja Auditor Pemerintah", Proceding SNA XIII, 2010.

www.gunungkidulkab.go.id, Diakses tanggal 25 Desember 2014 pk 20.00 WIB.

Yusuf, D. S., 2009, "Pengaruh Good Governance terhadap Kinerja Pemerintah Kota Bandung, Politeknik Pos Indonesia Bandung”. 